\title{
Medfødte misdannelser med basis i Medisinsk fødselsregister; tidstrender og mulige sammenhenger
}

\author{
Kari Klungsøyr \\ Avdeling for helseregistre, Folkehelseinstituttet, Zander Kaaes gate 7, 5015 Bergen \\ Institutt for global helse og samfunnsmedisin, Universitetet i Bergen, Kalfarveien 31, 5018 Bergen \\ Epost: kari.klungsoyr@fhi.no Mobil: 48215052
}

\begin{abstract}
This is an open access article distributed under the Creative Commons Attribution Licence, which permits unrestricted use, distribution, and reproduction
\end{abstract} in any medium, provided the original work is properly cited.

\section{MEDFØDTE MISDANNELSER}

Med medfødte misdannelser mener vi her strukturelle feil som oppstår under fosterutviklingen og kromosomfeil. Medfødte misdannelser er klart forbundet med økt dødelighet og sykelighet i nyfødtperioden og i barneår, og med funksjonshemminger på kort og lang sikt. De er også forbundet med økt risiko for spontanabort og dødfødsel (1). En del medfødte misdannelser oppdages umiddelbart etter fødsel, mens noen vil oppdages senere i livet. Imidlertid blir en økende andel misdannelser diagnostisert i løpet av svangerskapet, noe som igjen har medført at en økende andel fostre med medfødte misdannelser aborteres (2). Dette får konsekvenser både når man skal kartlegge forekomsten av medfødte misdannelser, og når man skal gjøre sykdomsbyrdeberegninger knyttet til medfødte misdannelser. Global burden of disease (GBD) prosjektet har rangert medfødte misdannelser som nr. 5 på listen over globale årsaker til død under 5 år, en oppgang fra nr. 7 i 1990 (3). Siden dødsfall forårsaket av misdannelser tenderer til å ramme tidlig i livet, blir byrden knyttet til antall tapte leveår stor også totalt sett $(3,4)$. GBD-beregningene inkluderer imidlertid ikke svangerskapsavbrudd som gjøres pga. medfødte misdannelser, og byrden av tapte leveår knyttet til medfødte misdannelser er derfor antagelig høyere enn det som rapporteres i GBD-prosjektet (5).

\section{THALIDOMIDKATASTROFEN OG OPPRETTEL- SEN AV MEDISINSK FØDSELSREGISTER}

Medisinsk fødselsregister (MFR) ble etablert i 1967, i kjølvannet av thalidomidkatastrofen, en situasjon der over 10000 barn globalt ble født med misdannelser i ekstremitetene som følge av at mødrene hadde tatt legemiddelet thalidomid i første trimester av svangerskapet (6). Denne hendelsen gjorde at man over hele verden innså betydningen av å etablere rutinemessig kartlegging av forekomsten av medfødte misdannelser, og misdannelsesregistre ble etablert i mange land. Som det eldste nasjonale medisinske fødselsregister i verden, har MFR siden 1967 hatt epidemiologisk overvåkning av medfødte misdannelser som ett av sine sentrale formål.

\section{TOLKNING AV TIDSTRENDER I FOREKOMST AV MEDFØDTE MISDANNELSER REGISTRERT I MFR}

Når 50 års tidstrender i forekomst av misdannelser registrert i MFR skal tolkes, er det flere ting å være opp- merksomme på: Endringer i forekomst kan være reelle, men man må også vurdere eventuelle endringer i innrapporteringen til registeret, endringer i kvalitetssikringsrutiner og andre metoder ved registeret, endringer i diagnostikk av misdannelsene og/eller endringer i demografiske kjennetegn i befolkningen som kan påvirke forekomsten.

\section{a. Endringer i innrapportering}

Innrapportering av medfødte misdannelser til MFR har gjennomgått noen store endringer i løpet av de siste 50 årene. Den første fødselsmeldingen, «Medisinsk registrering av fødsel», var i bruk nesten uendret fra 1967 til desember 1998. Denne meldingen var i hovedsak basert på fritekst, og opplysninger om medfødte misdannelser ble rapportert som svar på spørsmålet: «For levendefødte og dødfødte: Tegn på medfødt anomali, på skade eller sykdom?» Dersom man valgte svaralternativ «Ja», ble det etterspurt spesifisering, og fritekstdiagnosen ble så kodet ved MFR med kodeverket International Classification of Diseases versjon 8 (ICD-8). Informasjon om medfødte misdannelser ble bare innhentet fra føde-/barselavdeling, men diagnoser satt under oppholdet helt fram til utskrivning skulle inkluderes på meldingen, og oppholdet på barselavdeling var lengre enn det er i dag.

I desember 1998 ble det innført en ny fødselsmelding, der mye av informasjonen skulle registreres ved hjelp av kryssbokser. For medfødte misdannelser var det likevel i hovedsak ment at dette skulle formidles ved hjelp av beskrivende fritekst, og registeret gikk nå over til å bruke ICD-10 ved koding av fritekst. Den store endringen som skjedde parallelt med at den nye fødselsmeldingen ble innført var imidlertid at det ble innført melding fra nyfødtavdelinger for barn som ble overflyttet nyfødtmedisinsk intensivavdeling etter fødsel. Hensikten med dette var å bedre innrapportering av neonatale diagnoser inkludert medfødte misdannelser. Endringen med innrapportering av neonatale diagnoser fra nyfødtavdelingene hadde stor betydning for den registrerte forekomsten av medfødte misdannelser i MFR, spesielt for medfødte hjertefeil (Figur 1a). For medfødte hjertefeil økte forekomsten fra under 4 til over 9 per 1000 fra før til etter 1999. Det kan likevel synes som om de mest alvorlige hjertefeilene ble registrert også før 1999: foreløpig upubliserte data der forekomst av hjertefeil blant førstefødte barn i Sverige og Norge er sammenlignet viser at når man i Sverige setter som krav at hjertefeilen skal være registrert både i det svenske fødselsregisteret og i det svenske pasient- 
registeret (sykehusdiagnoser), er forekomsten svært lik i Norge og Sverige for årene før 1999 (Figur 1b).

En annen stor endring i innrapporteringen som også skjedde i 1999, var etableringen av et register for nemndbehandlede svangerskapsavbrudd, med lovpålagt innmelding av alle svangerskap som ble avbrutt etter 12 fullgåtte uker. Avbruddene ble meldt på eget skjema, men de svangerskapene som ble avbrutt etter abortlovens §2.3.c («fare for at barnet kan få alvorlig sykdom, som følge av arvelige anlegg, sykdom eller skadelige påvirkninger under svangerskapet») ble overført til MFR og lagret personidentifiserbart. Denne nye melderutinen har hatt stor betydning for å bedre den epidemiologiske overvåkningen av medfødte misdannelser. Etter hvert som flere og flere medfødte misdannelser kan diagnostiseres under svangerskapet, øker svangerskapsavbrudd som andel av totalforekomsten for mange medfødte misdannelser (Figur 2, Down syndrom).

Endringen er viktig å kjenne til når man skal studere effekter av forebyggende tiltak i forhold til misdannelser som har høye andeler svangerskapsavbrudd. Et eksempel er evaluering av anbefalingen om at kvinner som planlegger svangerskap bør ta folat perikonsepsjonelt. Dette ble en offisiell anbefaling på slutten av 1990-tallet i de fleste europeiske land, også i Norge fra 1998, i hovedsak for å forebygge nevralrørsdefekter $(7,8)$. Denne gruppen misdannelser inkluderer anencephalus, encephalocele, og spina bifida (ryggmargsbrokk). Prenatal diagnostikk av nevralrørsdefekter ble mulig med innføringen av ultralyd som rutinemessig screeningundersøkelse av alle gravide på slutten av 1980-tallet (9). Anencephalus er en misdannelse som ikke er forenlig med liv, og de fleste kvinner som får denne misdannelsen diagnostisert hos fosteret sitt under svangerskapet, velger avbrudd. Fra ultralydundersøkelser ble innført (og dermed muligheten for prenatal diagnostikk) og fram til innføring av meldeplikt for nemndbehandlede svangerskapsavbrudd i 1999, ble svangerskapsavbrudd på grunnlag av misdannelser underrapportert til MFR. Riktignok sa retningslinjene at svangerskapsavbrudd utført pga. medfødte misdannelser skulle meldes til MFR som dødfødte med misdannelsene spesifisert, men dette ble ofte ikke gjort. Registreringen av disse svangerskapene ble betraktelig bedret etter etableringen av Register for nemndbehandlede svangerskapsavbrudd. Hvis man dermed ønsker å evaluere effekten av anbefalingene om folat-tilskudd perikonsepsjonelt, vil det se ut som om anbefalingene har hatt motsatt effekt av det ønskede når det gjelder anencephalus-forekomst (Figur 3). Figur $3 \mathrm{~A}$ viser en liten, men jevn nedgang i forekomst av anencephalus fra 1967 til begynnelsen av 1990-tallet. Deretter øker forekomsten fra slutten av 90-tallet og fram til 2003, noe som ville kunne tas til inntekt for at anbefalingene om folattilskudd til gravide ikke har hatt effekt. Imidlertid kan den forbigående økningen i forekomst antagelig til en stor grad forklares av den bedrede registreringen av anencephalus pga. en bedret innrapportering av avbrutte svangerskap. Fra 2003 ser det derimot ut til at forekomsten har gått ned (Figur 3B).

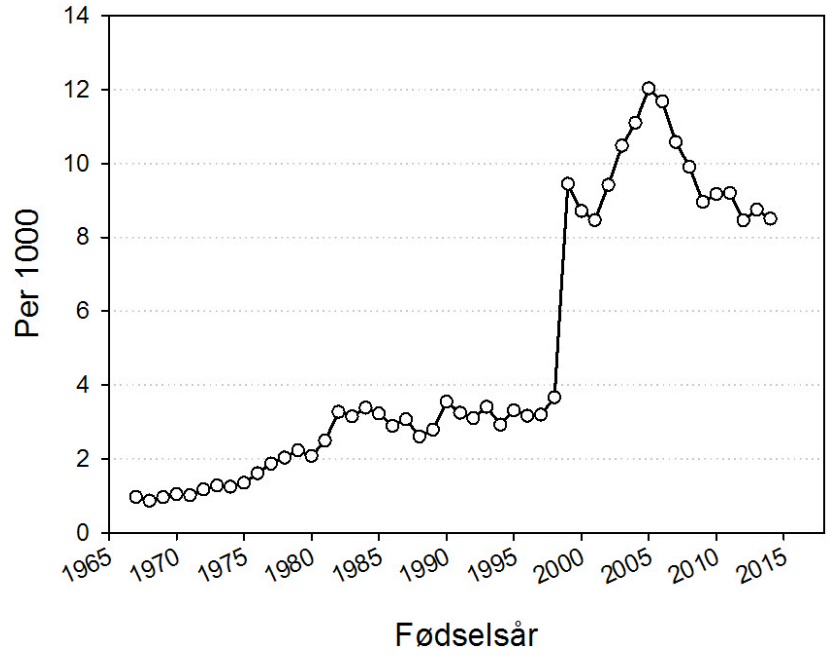

Figur 1a. Forekomst (per 1000) av alvorlige medfødte hjertefeil registrert i Medisinsk fødselsregister over tid, 1967-2014.

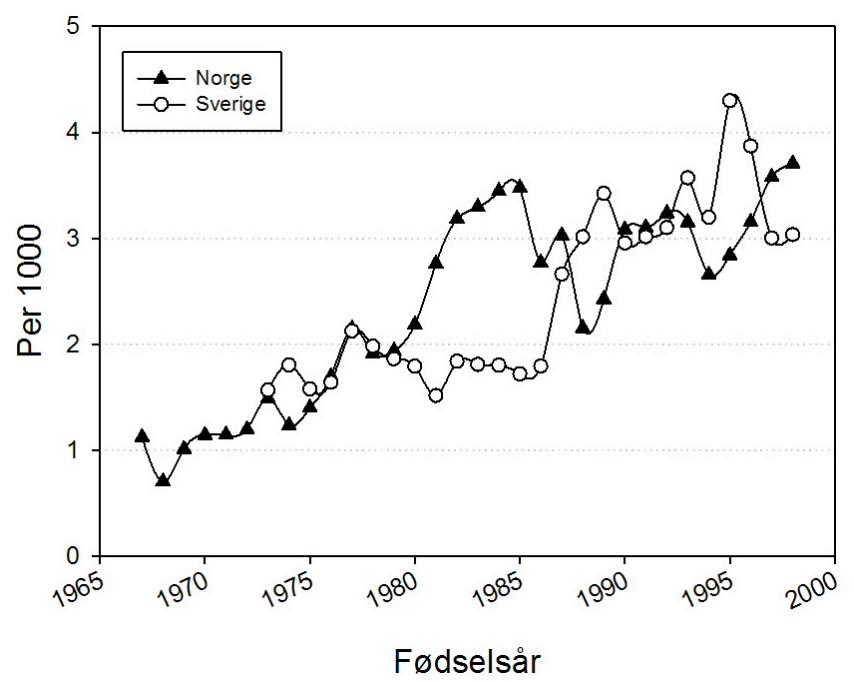

Figur 1b. Forekomst (per 1000) av alvorlige medfødte hjertefeil registrert i Norge (Medisinsk fødselsregister) og Sverige (registrert både i det svenske fødselsregisteret $o g \mathrm{i}$ det svenske pasientregisteret), 1967-1998.

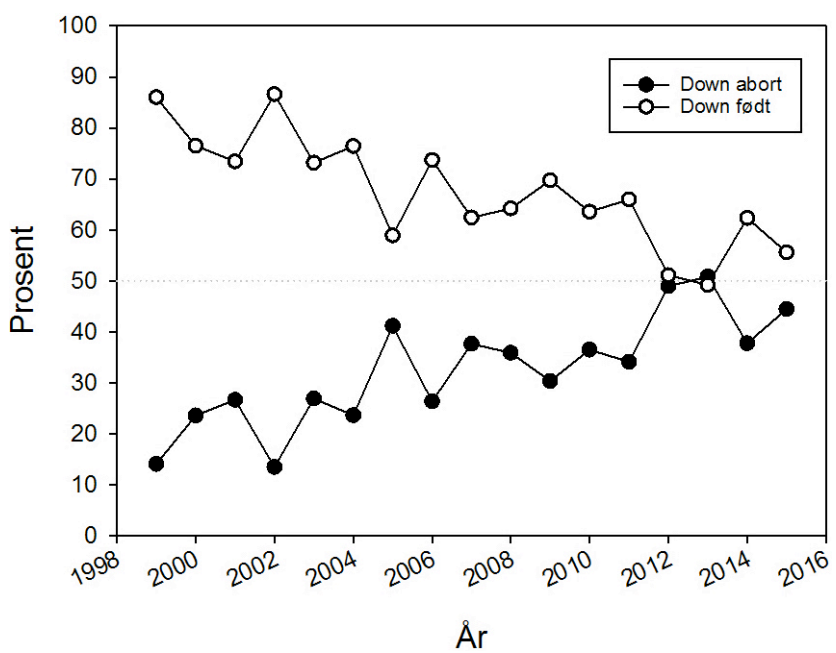

Figur 2. Andel (\%) av Down syndrom svangerskap som avbrytes (abort) og fullføres (født), registrert i Medisinsk fødselsregister, 1999-2015. 

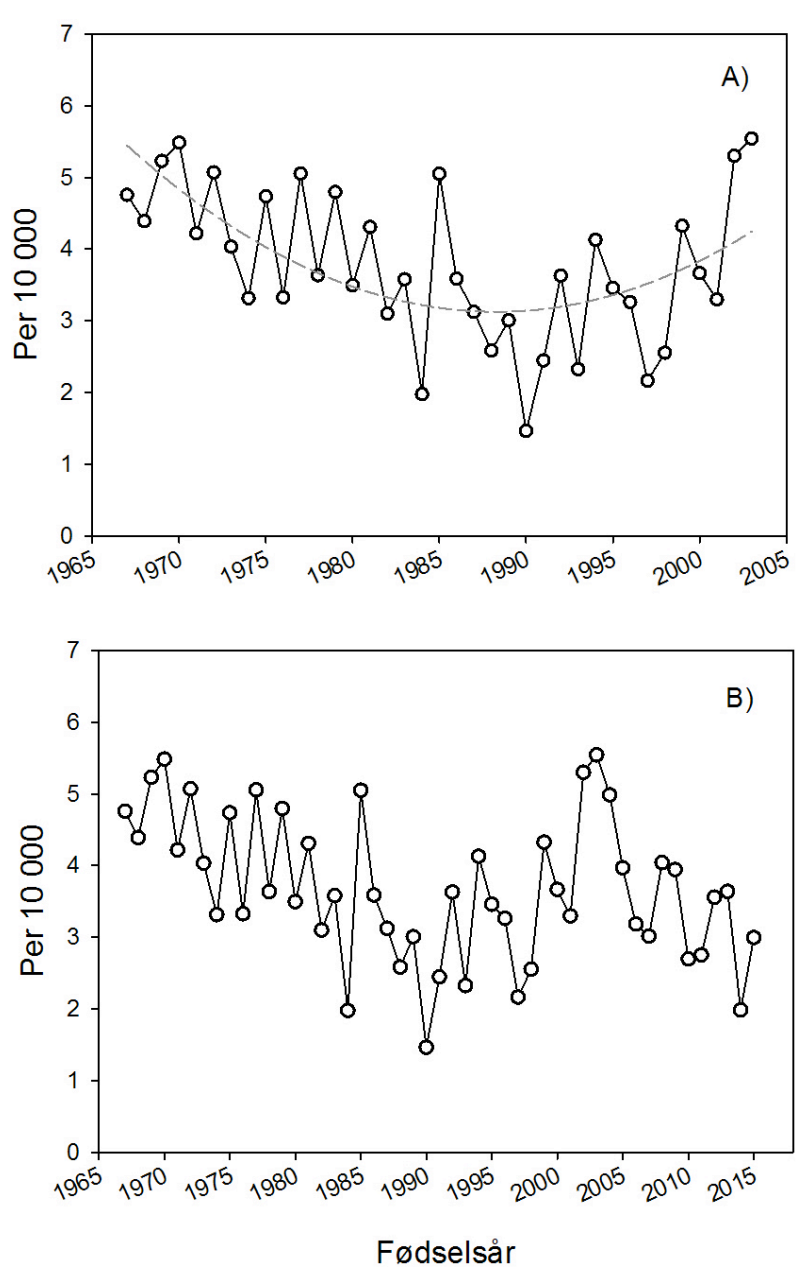

Figur 3. Forekomst (per 10000 ) av anencephalus registrert i Medisinsk fødselsregister fra A) 1967 til 2003 og B) fra 1967 til 2015.

\section{b. Endringer i diagnostikk}

Det har selvfølgelig skjedd store endringer i diagnostiske muligheter i løpet av 50 år. Muligheten til å stille diagnoser prenatalt ved hjelp av ultralyd er allerede nevnt. Prenatale kromosomanalyser etter fostervannsog morkakeprøver er andre eksempler på muligheten til å diagnostisere kromosomfeil før fødselen. Diagnostisering av medfødte hjertefeil etter fødselen ved hjelp av stadig mer avanserte ultralyd-, doppler- og ekko-undersøkelser, er et annet eksempel på endret diagnostikk. I MFR sine data kan det gi seg utslag i en økt rapportering av hjertefeil. Fra år 2001 til 2005 var det en tydelig økning i forekomsten av hjertefeil registrert i MFR (Figur 4). I 2005 mistenkte man ved registeret at denne økningen hovedsakelig skyldtes en bedret diagnostisering av mer uskyldige hjertefeil, men fra 2005 har forekomsten igjen gått ned.

Lignende trender er også beskrevet i andre europeiske land (10) og i en norsk artikkel av Leirgul og medarbeidere fra 2014 (11), som ser på forekomst av medfødte hjertefeil fra 1994 til 2009. I Leirguls studie hadde forskerne informasjon om hjertefeil fra flere kilder enn MFR, blant annet fra hjertefeil-registeret ved Rikshospitalet og fra CVDNOR, en forskningsdatabase med informasjon om hjertesykdom hentet fra norske

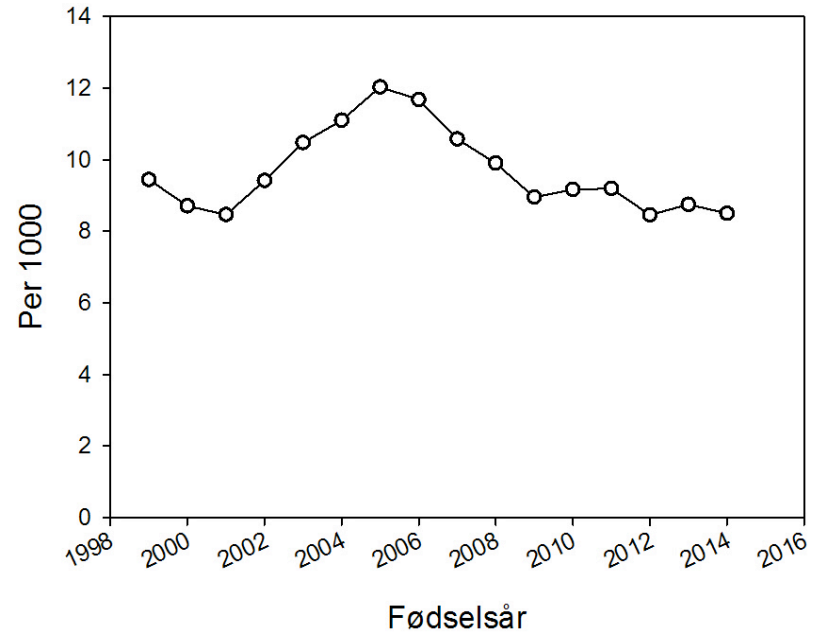

Figur 4. Forekomst (per 1000) av alvorlige hjertefeil registrert i Medisinsk fødselsregister over tid.

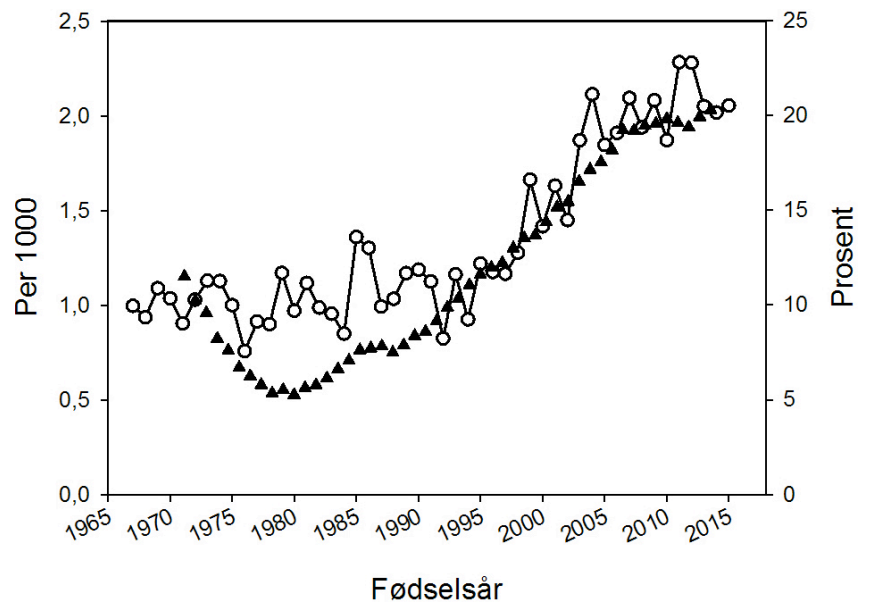

Figur 5. Forekomst (per 1000) av Down syndrom registrert i Medisinsk fødselsregister (åpne rundinger) og \% kvinner som er 35 år eller mer når de føder (svarte trekanter), 1967-2015.

sykehus (12). Endringene i forekomst av hjertefeil fra 1999-2014 skyldes dermed antagelig ikke bare bedret diagnostikk, og mulige årsaker til nedgangen i forekomst fra 2005 diskuteres i Leirguls arbeid.

\section{c. Endringer i demografiske karakteristika}

Det mest påfallende eksempelet på betydningen av endrede demografiske karakteristika i fødepopulasjonen er kanskje tidstrenden i forekomst av Down syndrom (Figur 5). Totalforekomsten av Down syndrom registrert i MFR lå stabilt rundt ca. 1 per 1000 fram til 1994. Deretter steg den jevnt fram til 2004, før den flatet noe mer ut på ca. 2 per 1000 . Den viktigste årsaken til denne stigningen er økningen i mors alder ved fødsel, ettersom risikoen for å få et barn med Down syndrom øker signifikant med økende alder hos mor (13). Den gjennomsnittlige alderen hos kvinner som føder har økt jevnt og trutt siden begynnelsen av 1970-tallet, og andelen kvinner som er over 35 år og over 40 år når de føder barn har økt i takt med den (Figur 5). 
En annen viktig demografisk endring i Norge er den økende andelen barn som fødes av ikke-vestlige innvandrere. Andelen kvinner med diabetes inkludert svangerskapsdiabetes er høyere hos kvinner fra NordAfrika og det indiske subkontinent, og diabetes i svangerskapet øker risikoen for medfødte misdannelser hos fosteret, kanskje særlig medfødte hjertefeil $(14,15)$.

\section{EPIDEMIOLOGISK OVERVÅKNING AV MED- FØDTE MISDANNELSER REGISTRERT I MFR}

Når man tar alle de ovenfor nevnte vurderingene med $\mathrm{i}$ betraktning, er det likevel mulig å evaluere trender og opphopninger av medfødte misdannelser. Som nevnt var epidemiologisk overvåkning av misdannelser ett av hovedformålene til MFR da registeret ble etablert etter thalidomidkatastrofen. Forskjellige metoder for overvåkningsanalyser har vært brukt; en oversikt er gitt av Rolv Terje Lie et al. (16). Flere tilfeller med høyere enn forventet forekomst av spesifikke misdannelser har blitt påvist og undersøkt i løpet av de årene denne overvåkningen pågikk, blant annet gastroschise og hofteleddsdysplasi (17). I de senere år har overvåkningsanalyser ved MFR i hovedsak skjedd i samarbeid med European Surveillance of Congenital Anomalies (EUROCAT) nettverket (se under).

\section{ÅRSAKER TIL MEDFØDTE MISDANNELSER}

Det er fortsatt mye vi ikke vet om årsaker til medfødte misdannelser. Genetiske faktorer inkludert gen-miljø interaksjoner er viktige, mors alder er av betydning spesielt for kromosomfeil, noen misdannelser kan skyldes eksponering for miljøfaktorer gjennom arbeid eller miljøforurensning, noen skyldes sykdommer hos mor (for eksempel diabetes), eller visse infeksjoner under svangerskapet (for eksempel røde hunder), noen skyldes ernæringsforhold (for eksempel folatmangel), noen skyldes livsstilsfaktorer som røyking og alkohol, og noen skyldes at mor har brukt legemidler med teratogen effekt $\mathrm{i}$ første trimester, som eksemplifisert ved thalidomidkatastrofen.

I likhet med de andre populasjonsbaserte registrene i Norden, inneholder MFR fødselsnumre på de registrerte individene. Dette gjør det mulig å koble MFR med andre registre, og også koble individer innenfor MFR i familie enheter. Denne muligheten har vært brukt i flere viktige studier av medfødte misdannelser basert på data fra MFR. I 1994 publiserte for eksempel Lie og medarbeidere en studie i New England Journal of Medicine om risikoen for å gjenta medfødte misdannelser hos avkom i påfølgende svangerskap (18). Denne studien anvendte et søskenflokkdesign, der barna ble koblet til sine mødre i søskenflokker slik at mor utgjorde analyse-enheten. Med dette designet fant forskerne at kvinner som hadde hatt et misdannet barn i sitt første svangerskap i gjennomsnitt hadde 2,5 ganger så høy risiko for å få et misdannet barn også i sitt andre svangerskap sammenlignet med kvinner som ikke hadde misdannede barn i første svangerskap. Den økte gjentagelsesrisikoen var drevet fram av en mer enn 7 ganger økt risiko for å gjenta den samme organspesifikke misdannelsestypen i de to svangerskapene, mot en $50 \%$ økt risiko, fortsatt signifikant, for en annen misdannelsestype i det andre enn det første svangerskapet.

Data i MFR kan også struktureres i generasjonsenheter der barn født i de første tidsperiodene av registeret kobles med egne barn født i siste del av registerperioden. Som det eldste populasjonsbaserte medisinske fødselsregister i verden, leder MFR an når det gjelder generasjonsstudier. Eksempler på dette er to viktige generasjonsstudier om medfødte misdannelser gjort med basis i MFR: I en artikkel fra 1999, også publisert i New England Journal of Medicine, vurderte Skjærven og medarbeidere om kvinner født med en medfødt misdannelse hadde høyere risiko for selv å få misdannede barn sammenlignet med kvinner som ikke hadde misdannelser (19). Også dødelighet og reproduksjonsrater assosiert med misdannelsene ble beskrevet. Forskerne konkluderte med at det er en høyere dødelighet og en lavere reproduksjonsrate blant kvinner som selv har en misdannelse, og at det også er $ø k t$ risiko for misdannelser hos egne barn. Et positivt budskap var likevel at den økte risikoen for misdannelser hos eget avkom var begrenset til den samme organspesifikke misdannelsestypen, og at det ikke var høyere risiko for andre typer misdannelser hos avkommet. Forskerne gikk videre og studerte de samme spørsmålene for fedre (20). Fedre med misdannelser hadde også økt risiko for misdannelser hos avkommet, men et uventet funn var at affiserte fedre også så ut til å ha en generell økt risiko for å videreføre misdannelser til neste generasjon uavhengig av misdannelsestype. Riktignok var det høyest risiko for at barna skulle få samme organspesifikke misdannelse som fedrene selv, men det var også en signifikant økt risiko for andre misdannelsestyper. Andelen medfødte misdannelser $\mathrm{i}$ andre generasjon som kunne tilskrives at mor eller far hadde en misdannelse var dessuten høyere når det var far som hadde en medfødt misdannelse enn når det var mor. Disse tre studiene som alle benytter familiedata i sine analyser indikerer at genetiske faktorer er av betydning for medfødte misdannelser.

Forskning på årsaker til medfødte misdannelser kompliseres imidlertid av flere grunner, blant annet at de er sjeldne: Samlet sett ligger forekomsten av alvorligere misdannelser på 2-3\%, men hvis man skal studere spesifikke misdannelser, som er nødvendig når man skal finne spesifikke årsaksfaktorer, ligger forekomsten av de vanligste (f.eks hjertefeil, nevralrørsdefekter og leppe-ganespalte) på ca. 1-2 per 1000 i Norge (http://statistikkbank.fhi.no/mfr/). De sjeldnere ligger på noen få tilfeller per 10000 og lavere.

For å kunne gjøre meningsfulle analyser er det derfor nyttig å samarbeide internasjonalt. MFR er med $i$ to internasjonale nettverk som fokuserer på medfødte misdannelser, det globale International Clearinghouse 
for Birth Defects Surveillance and Research (Clearinghouse) og det europeiske nettverket EUROCAT. Av disse er spesielt EUROCAT-samarbeidet viktig. EUROCAT er et nettverk av populasjonsbaserte misdannelsesregistre i Europa som har operert i over 35 år og som i dag dekker $31 \%$ av europeiske fødsler (21). Det som gjør EUROCAT-samarbeidet ekstra viktig er den sentrale databasen som årlig mottar anonymiserte individdata om medfødte misdannelser fra alle registrene som er «full members». Disse registrene sender anonyme individ-data om misdannelsestilfeller blant levendefødte, dødfødte fra 20 svangerskapsuker og svangerskapsavbrudd etter en standardisert mal hvert år, i tillegg til aggregerte opplysninger om antall fødsler totalt. Den sentrale databasen kan dermed brukes til årsaksforskning om medfødte misdannelser med et helt annet antall tilfeller enn om hvert enkelt land skulle gjøre disse analysene alene. I tillegg gjøres det epidemiologiske overvåkningsanalyser sentralt, både for alle registrene totalt og for hvert enkelt register, med utgangspunkt i denne databasen (22).

Innenfor EUROCAT-nettverket er det en egen ekspertgruppe som jobber spesifikt med koding og klassifisering av medfødte misdannelser. Denne gruppen har laget en definisjon av såkalt «alvorlige medfødte misdannelser» inndelt i organspesifikke subgrupper, og disse definisjonene er publisert på internett og brukes i studier som EUROCAT-nettverket gjør på feltet (23). Per i dag finnes det ikke noen internasjonal faglig konsensus over hva som skal defineres som «alvorlige misdannelser»: Det er generell enighet om at bagatellmessige misdannelser som ikke er assosiert med funksjonsnedsettelse eller krever behandling bør ekskluderes i studier av medfødte misdannelser, men hvilke misdannelser som blir definert som bagatellmessige kan variere. Siden EUROCAT sin definisjon er publisert og kan brukes av alle som ønsker det, er dette i det minste en mulighet til å anvende like definisjoner når man skal studere medfødte misdannelser.

EUROCAT har gjennomført studier både når det gjelder forholdet mellom miljøfaktorer og misdannelser, for eksempel sammenhengen mellom Tsjernobylulykken og misdannelser (der man konkluderte med manglende sammenheng (24)), mellom mors sykdommer som diabetes og misdannelser (14) og mellom legemiddelbruk i svangerskapet og misdannelser (2527, 29-30). Sistnevnte studier har også blitt videreført i et eget forskningsprosjekt der man koblet EUROCATdata med andre databaser som hadde opplysninger om legemiddelbruk i svangerskapet, EUROmediCAT (28). I Norge ble MFR koblet med Nasjonalt reseptbasert legemiddelregister (Reseptregisteret). Gjennom EUROCAT og EUROmediCAT er sammenhengen mellom flere typer legemidler og medfødte misdannelser evaluert, for eksempel forskjellige typer antiepileptika $(25,26,29,30)$, SSRI $(27,31)$, antiastmatika (32) og flere.

Etter at sammenhengen mellom perikonsepsjonelt folat tilskudd og nevralrørsdefekter ble fastslått gjen- nom blant annet randomiserte studier på 1980-og 90tallet (33), har EUROCAT også hatt en arbeidsgruppe som har fokusert spesielt på forholdet mellom folat og misdannelser. I en trendanalyse fra 2015 konkluderer Khoshnood og medarbeidere imidlertid med at til tross for anbefalingene om å ta folat perikonsepsjonelt $i$ europeiske land der beriking med folat i matvarer ikke er implementert, har det ikke vært en klar nedgang i forekomst av nevralrørsdefekter (34).

MFR sine data har også vært brukt til å evaluere årsaker til medfødte misdannelser i flere andre registerbaserte prosjekter, både basert på MFR-data alene, men også andre internasjonale samarbeidsprosjekter. Ett eksempel er et stort nordisk prosjekt der en av studiene også så på forholdet mellom legemiddelbruk i svangerskapet og medfødte misdannelser (35). Her ble fødsels- og legemiddelregistre i Norden koblet, og man evaluerte forholdet mellom mors bruk av SSRI og venlafaksin i første trimester og medfødte misdannelser hos avkommet. I motsetning til det blant annet EUROCAT-studier på feltet konkluderer med, fant forskerne $\mathrm{i}$ denne studien ingen klar sammenheng mellom SSRI/venlafaksin brukt i svangerskapet og alvorlige medfødte misdannelser, blant annet basert på en søskenanalyse som gjorde det mulig å indirekte justere for ikke-målte konfunderende faktorer. Ulempen med denne studien er imidlertid at forskerne bare hadde informasjon om medfødte misdannelser blant levendefødte barn.

Et annet stort og viktig prosjekt som også har brukt data delvis fra MFR, er en norsk kasus-kontroll-studie om leppe-ganespalter (36). Rekruttering av leppeganespaltebarn født fra 1967 til 2001 skjedde fra de to sykehusene som opererer leppe-ganespalte i Norge, Oslo universitetssykehus - Rikshospitalet og Haukeland universitetssjukehus. Kontroll-barn ble selektert fra Det sentrale folkeregister og data fra MFR om både spaltebarna og kontrollene ble innhentet. I tillegg samlet man inn data både fra spørreskjemaer og fra biologiske prøver. Prosjektet har vært grunnlag for utallige studier både om genetiske risikofaktorer for leppe-ganespalte (for eksempel (37)) og sammenheng mellom livsstil- og miljøfaktorer og spalter, for eksempel røyking (38), kaffe (39), og alkohol (40). Også gen-miljø interaksjoner har vært studert (41).

\section{KONKLUSJON}

MFR har siden opprettelsen i 1967 hatt et stort fokus på både epidemiologisk overvåkning av medfødte misdannelser og forskning på årsaker til og konsekvenser av disse. Data fra registeret har vært brukt $i$ utallige forskningsprosjekter på feltet, og har bidratt til økt kunnskap både om mulige årsaksfaktorer og om muligheter for forebyggende tiltak. Med dagens elektroniske innrapportering til registeret både fra føde-/ barselavdelinger og fra nyfødtavdelinger blir data om medfødte misdannelser raskere tilgjengelig, noe som er viktig for meningsfulle overvåkningsanalyser. 
Muligheten til kobling av de registrerte individene i familieenheter, samt kobling med andre registre og biobanker, gjør MFR til en unik datakilde. Det er et ønske at data fra MFR også i fremtiden vil tjene som et viktig datagrunnlag for studier om årsaker til og konsekvenser av medfødte misdannelser.

\section{REFERANSER}

1. Groen H, Bouman K, Pierini A, et al. Stillbirth and neonatal mortality in pregnancies complicated by major congenital anomalies: findings from a large European cohort. Prenat Diagn 2017 Aug 24. doi: 10.1002/pd.5148 [Epub ahead of print].

2. Boyd PA, Devigan C, Khoshnood B, et al. Survey of prenatal screening policies in Europe for structural malformations and chromosome anomalies, and their impact on detection and termination rates for neural tube defects and Down's syndrome. BJOG 2008; 115: 689-96.

3. GBD 2015 Child Mortality Collaborators. Global, regional, national, and selected subnational levels of stillbirths, neonatal, infant, and under-5 mortality, 1980-2015: a systematic analysis for the Global Burden of Disease Study 2015. Lancet 2016; 388: 1725-74.

4. GBD 2015 Mortality and Causes of Death Collaborators. Global, regional, and national life expectancy, allcause mortality, and cause-specific mortality for 249 causes of death, 1980-2015: a systematic analysis for the Global Burden of Disease Study 2015. Lancet 2016; 388: 1459-1544.

5. Boyle B, Addor MC, Arriola L, et al. Estimating Global Burden of Disease due to congenital anomaly: an analysis of European data. Arch Dis Child Fetal Neonatal Ed 2017. doi: 10.1136/archdischild-2016-311845 (Epub ahead of print).

6. Irgens L. The Medical Birth Registry of Norway. Epidemiological research and surveillance throughout 30 years. Acta Obstet Gynecol Scand 2000; 79: 435-9.

7. Cawley S, Mullaney L, McKeating A, et al. A review of Euoropean guidelines on periconceptional folic acid supplementation. Eur J Clin Nutr 2016; 70: 143-54.

8. https://www.fhi.no/fp/gravide-og-fodende-kvinners-helse/folat---folattilskudd-og-svangerska/ (Oppslag 09.09.2017).

9. Kvande L. Frå politikk til etikk - obstetrisk ultralyd i 1980- og 90-åra. Tidsskr Nor Legeforen 2008; 128: 2855-9.

10. Khoshnood B, Loane M, Garne E, et al. Recent decrease in the prevalence of congenital heart defects in Europe. J Pediatr 2013; 162: 108-113.e2.

11. Leirgul E, Fomina T, Brodwall K, et al. Birth prevalence of congenital heart defects in Norway 1994-2009 - a nationwide study. Am Heart J. 2014; 168: 956-64.

12. CVDNOR cardiovascular disease in Norway. https://cvdnor.b.uib.no (Oppslag 09.09.2017).

13. Loane M, Morris JK, Addor MC, et al. Twenty-year trends in the prevalence of Down syndrome and other trisomies in Europe: impact of maternal age and prenatal screening. Eur J Hum Genet 2013; 21: 27-33. doi: 10.1038/ejhg.2012.94.

14. Garne E, Loane M, Dolk H, et al. Spectrum of congenital anomalies in pregnancies with pregestational diabetes. Birth Defects Res A Clin Mol Teratol 2012; 94: 134-40. doi:10.1002/bdra.22886.

15. Leirgul E, Brodwall K, Greve G, et al. Maternal diabetes, birth weight, and neonatal risk of congenital heart defects in Norway, 1994-2009. Obstet Gynecol 2016; 128: 1116-25.

16. Lie RT, Vollset SE, Botting B, Skjærven R. Statistical methods for surveillance of congenital malformations: when do the data indicate a true shift in the risk that an infant is affected by some type of malformation? Int $J$ Risk Saf Med 1991; 2: 289-300. doi: 10.3233/JRS-1991-2506.

17. https://www.fhi.no/hn/helseregistre-og-registre/mfr/medisinsk-fodselsregister--historis/ (Oppslag 09.09.2017).

18. Lie RT, Wilcox AJ, Skjærven R. A population-based study of the risk of recurrence of birth defects. $N$ Engl $J$ Med 1994; 331: 1-4.

19. Skjærven R, Wilcox AJ, Lie RT. A population-based study of survival and childbearing among female subjects with birth defects and the risk of recurrence in their children. $N$ Engl J Med 1999; 340: 1057-62.

20. Lie RT, Wilcox AJ, Skjærven R. Survival and reproduction among males with birth defects and risk of recurrence in their children. JAMA 2001; 285: 755-60.

21. Boyd PA, Haeusler M, Barisic I, et al. Paper 1: The EUROCAT network - organization and processes. Birth Defects Res A Clin Mol Teratol 2011; 91 (Suppl 1): S2-15. doi: 10.1002/bdra.20780.

22. Loane M, Dolk H, Kelly A, et al. Paper 4: EUROCAT statistical monitoring: identification and investigation of ten year trends of congenital anomalies in Europe. Birth Defects Res A Clin Mol Teratol 2011; 91 (Suppl 1): S31-43. doi: 10.1002/bdra.20778.

23. http://www.eurocat-network.eu/aboutus/datacollection/guidelinesforregistration/malformationcodingguides (Oppslag 09.09.2017).

24. Dolk H, Nichols R. Evaluation of the impact of Chernobyl on the prevalence of congenital anomalies in 16 regions of Europe. EUROCAT Working Group. Int J Epidemiol 1999; 28: 941-8. 
25. Jentink J, Dolk H, Loane MA, et al. Intrauterine exposure to carbamazepine and specific congenital malformations: systematic review and case-control study. BMJ 2010; 341: c6581. doi: 10.1136/bmj.c6581.

26. Jentink J, Loane MA, Dolk H, et al. Valproic acid monotherapy in pregnancy and major congenital malformations. N Engl J Med 2010; 362: 2185-93.

27. Wemakor A, Casson K, Garne E, et al. Selective serotonin reuptake inhibitor antidepressant use in first trimester pregnancy and risk of specific congenital anomalies: a European register-based study. Eur J Epidemiol 2015; 30: 1187-98.

28. de Jonge L, Garne E, Gini R, et al. Improving information on maternal medication use by linking prescription data to congenital anomaly registers: A EUROmediCAT study. Drug Saf 2015; 38: 1083-93.

29. Dolk H, Wang H, Loane M, et al. Lamotrigine use in pregnancy and risk of orofacial cleft and other congenital anomalies. Neurology 2016; 86: 1716-25.

30. Dolk H, Jentink J, Loane M, et al. Does lamotrigine use in pregnancy increase orofacial cleft risk relative to other malformations? Neurology 2008; 71: 714-22.

31. Jordan S, Morris JK, Davies GI, et al. Selective serotonin reuptake inhibitor (SSRI) antidepressants in pregnancy and congenital anomalies: analysis of linked databases in Wales, Norway and Funen, Denmark. PLoS One 2016; 11: e0165122. doi: 10.1371/journal.pone.0165122.

32. Garne E, Vinkel Hansen A, Morris J, et al. Risk of congenital anomalies after exposure to asthma medication in the first trimester of pregnancy - a cohort linkage study. BJOG 2016; 123: 1609-18.

33. MRC Vitamin Study Research Group. Prevention of neural tube defects: results of the Medical Research Council Vitamin Study. Lancet 1991; 338: 131-7.

34. Khoshnood B, Loane M, de Walle H, et al. Long term trends in prevalence of neural tube defects in Europe: population based study. BMJ 2015; 351: h5949. doi: 10.1136/bmj.h5949.

35. Furu K, Kieler H, Haglund B, et al. Selective serotonin reuptake inhibitors and venlafaxine in early pregnancy and risk of birth defects: population based cohort study and sibling design. BMJ 2015; 350: h1798. . doi: 10.1136/bmj.h1798.

36. Wilcox AJ, Lie RT, Solvoll K et al. Folic acid supplements and risk of facial clefts: national population based case-control study. BMJ 2007; 334: 464.

37. Jugessur A, Shi M, Gjessing HK, et al. Genetic determinants of facial clefting: analysis of 357 candidate genes using two national cleft studies from Scandinavia. PLoS One 2009; 4: e5385. doi: 10.1371/journal.pone.0005385.

38. Lie RT, Wilcox AJ, Taylor J, et al. Maternal smoking and oral clefts: the role of detoxification pathway genes. Epidemiology 2008; 19: 606-15.

39. Johansen AM, Wilcox AJ, Lie RT, et al. Maternal consumption of coffee and caffeine-containing beverages and oral clefts: a population-based case-control study in Norway. Am J Epidemiol 2009; 169: 1216-22.

40. DeRoo LA, Wilcox AJ, Drevon CA, Lie RT. First-trimester maternal alcohol consumption and the risk of infant oral clefts in Norway: a population-based case-control study. Am J Epidemiol 2008; 168: 638-46.

41. Skare O, Jugessur A, Lie RT, et al. Application of a novel hybrid study design to explore gene-environment interactions in orofacial clefts. Ann Hum Genet 2012; 76: 221-36. 